AGH DRILLING, OIL, GAS • Vol. 32 • No. $1 \cdot 2015$

http://dx.doi.org/10.7494/drill.2015.32.1.77

\author{
Stanisław Dubiel*, Czesław Rybicki*, \\ Adam Zubrzycki*, Michał Maruta*
}

\title{
APPLICABILITY OF DST RESULTS TO THE EVALUATION OF CHANGES OF GEOLOGIC CONDITIONS OF ROTLIEGEND SERIES IN THE POLISH LOWLAND**
}

\section{INTRODUCTION}

The testing of perspective horizons with a Drill Stem Tester (DST) provides important data, on the basis of which reservoir rock horizons saturated with hydrocarbons can be determined, samples of reservoir fluid can be collected and hydrodynamic tests performed in uncased wells. The perspective horizons can be tested while drilling reservoir rock horizons or after drilling a well to the planned depth. The advantage of DST tests while drilling is the higher quality and reliability of the obtained data caused by the fact that permeability of reservoir rock is less damaged by filtrate and solid phase of the mud. When the duration of the mud contact with the reservoir horizon elongates, the damage to permeability in the wellbore area increases and the probability of obtaining good quality data is smaller. The technologically successful DST tests of perspective horizons can be performed in almost all geologic conditions if they are preceded by a thorough recognition of the technical state of the well and experience with the oil prospecting area is accounted for.

In wells sited on compact and sandy rocks (i.e. Rotliegend), the use of special sampling technology with a set of testers and a data acquisition method for the interpretation of geologic-reservoir data should be considered.

\section{GEOLOGICAL SETTING OF ROTLIEGEND HORIZON}

The Rotliegend series of clastic sediments in the area of the Polish Lowlands have been a very important gas-bearing formation for the last 50 years. The first gas field

* AGH University of Science and Technology, Faculty of Drilling, Oil and Gas, Krakow, Poland

** Work performed within the statutory research program of the Faculty of Drilling, Oil and Gas AGH UST 
in Bogdaj-Uciechów was discovered in 1964 making petroleum exploration in the Wielkopolska Petroleum Province (part of the Polish Permian Basin) valid for petroleum industry in Poland.

The Polish Rotliegend Basin (PRB) is an eastern part of the great European Southern Rotliegend Basin extending from England through the North Sea, Germany to Poland. Here it has an asymmetric tectonic structure and is divided into the Central Basin in the north and the Wielkopolska Subbasin being separated from the Lower Silesian Subbasin by the Wolsztyn Ridge in the south. In this area the PRB is located on folded and strongly eroded Variscan basement. The development of this sedimentary basin started in the latest Carboniferous and prolonged to the earliest Zechstein in the form of a clastic sedimentation conditioned by two main factors: tectonics and arid climate. The origin and development of PRB within the area of the Polish Lowlands was analyzed by Karnkowski [6]. The analysis of depositional systems and facies characterization was performed by Kiersnowski [7], whereas the results of studies of Rotliegend sediment reservoir properties and the petroleum system of the PRB were published in [11, 8] and [5]. The profile of Rotliegend sediments was very well recognized by numerous petroleum drillings particularly in the area of Wielkopolska and Lower Silesian Subbasins near the margin zones of the Wolsztyn Ridge (Fig. 1).

The system of tectonic grabens and horts within the Paleozoic basement is the determining factor for the thickness arrangement of the Rotliegend sediments in this area. As a rule these are different pink to red and red brown clastic sediments: from coarsegrained (conglomerates) to finest-grained (siltstones and mudstones) formed in continental subtropical conditions, which with time evolved into desert conditions. The upper part of the Rotliegend profile is represented by desert sediments: dune and interdune sandstones and deposits of seasonal rivers (wadi) as alluvial fans and fluvial channels. Aeolian sandstones are reservoir rocks with different reservoir properties. According to [11] the effective porosity $\Phi$ eff ranges from $2 \%$ to $25 \%$ and permeability $K$ is from 0.0 to a few hundreds $\mathrm{mD}$, depending on the depth (compaction level), cementation and authigenic illite content. Fluvial sandstones (mainly fluvial channels in type) are characterized by $\Phi$ eff ranging from $1 \%$ to $25 \%$ and $K=0.0$ to $100 \mathrm{mD}$. For alluvial fan sandstones $\Phi$ eff is about $5 \%$ and $K$ about $1 \mathrm{mD}$. Such phenomena demonstrate rapid transitions between aeolian and fluvial facies within the reservoir horizons. Natural gas accumulations are usually discovered in the uppermost series of the Rotliegend sandstones and often in the overlying Zechstein Limestone of the Werra Cyclotheme PZ1 in structural and stratigraphic traps often cut by faults. Sealing rocks are formed by overlying Zechstein evaporates a few hundred meters thick. Natural gases contain hydrocarbons, 15 to $60 \%$ of nitrogen and 0.1 to 0.3 of helium. As an example of such trap can be Środa Wielkopolska gas field discovered in 2005 while drilling ŚW-4 well. Here natural gas is accumulated in the top part of buried palaeodune cut from southwestern side by a steep fault. Aeolian sandstones were drilled in depth range of 3568 to $3701 \mathrm{~m}$. After DST tests the commercial gas production was received from the uppermost part of them in a depth interval of 3568-3580 $\mathrm{m}$. The assessment of the gasbearing productivity indices of the Rotliegend was based on testing results in a directional well G-1k [10]. 


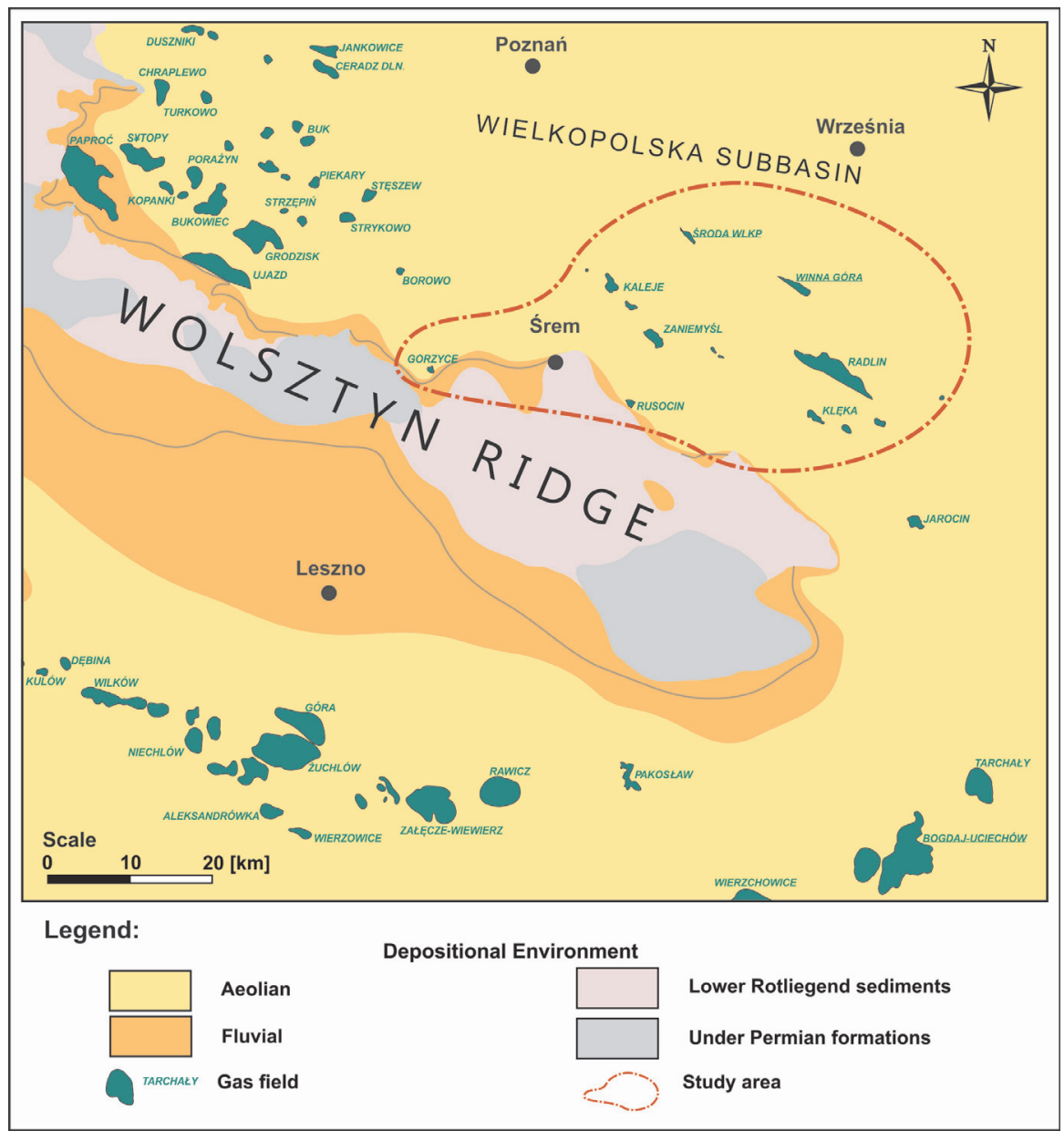

Fig. 1. The study area on the background of the Wielkopolska Rotliegend Subbasin (North) separated by the Wolsztyn Ridge from the Lower Silesian Basin (South) [8]

\section{TECHNIQUE AND TECHNOLOGY OF TESTING G-1K WELL}

The roof of the perspective horizon of the Rotliegend was drilled at $3351.7 \mathrm{~m}$ of depth (MD). While drilling in the Rotliegend natural gas manifestations in mud and cores were observed under the shoe of the last casing column 7" (tripped to $3325 \mathrm{~m}$ of depth (MD). These manifestations were an important clue informing about the perspective value of the horizon and created bases for installing a Standard Halliburton drill stem tester 3 7/8" with packer (Tab. 1) over the cement plug, the top of which was deposited at $3371 \mathrm{~m}$ of depth (MD). In this way the Rotliegend was selectively tested with the increasing depth (3351.7-3366.0 m (MD); 3113.0-3125.8 m (TVD). 
Table 1

Elements of a drill stem tester used for testing the Rotliegend in G-1k well [10]

\begin{tabular}{|c|c|c|c|}
\hline Element & $\begin{array}{l}\text { Length } \\
{[\mathrm{m}]}\end{array}$ & Element & $\begin{array}{l}\text { Length } \\
{[\mathrm{m}]}\end{array}$ \\
\hline Shoe $37 / 8 "+$ sieve $37 / 8 "+$ sub & 3.51 & $\begin{array}{l}\text { Diaphragm circulation } \\
\text { valve } 3-1 / 2 " \text { IP }\end{array}$ & 0.30 \\
\hline Tubing pup joint 3 1/2" & 1.38 & DC 4-3/4" & 28.21 \\
\hline HWDP 3-1/2" & 18.61 & HWDP 3-1/2" & 83.80 \\
\hline $\begin{array}{l}\text { Sieve } 37 / 8 \text { "+x/o cz 3-1/2"IFxm } \\
\text { 2-3/8"IF }\end{array}$ & 1.77 & DP 3-1/2" & 3202.65 \\
\hline Safety sub 7/8" & 1.19 & Tubing pup joint $31 / 2^{\prime \prime}$ & 4.83 \\
\hline Packer NR 5 1/2" & 1.50 & $\begin{array}{l}\text { Surface wellhead: valve under } \\
\text { wellhead, }\end{array}$ & - \\
\hline Safety sub VR $37 / 8^{\prime \prime}$ & 0.78 & $\begin{array}{l}\text { rotary head, safety valve, } \\
\text { manifold with }\end{array}$ & - \\
\hline Hydraulic shears $37 / 8 "$ & 1.52 & replaceable orifices, pipelines, & - \\
\hline Electr.regist.case $37 / 8 "$ & 1.50 & $\begin{array}{l}\text { separation system, combustion } \\
\text { system, }\end{array}$ & - \\
\hline Main valve $37 / 8^{\prime \prime}$ & 2.07 & gas measurement system & - \\
\hline Autoclave $37 / 8 "$ & 0.77 & - & - \\
\hline Rotary valve $37 / 8 "$ & 2.10 & - & - \\
\hline DC 4-3/4" & 28.31 & - & - \\
\hline
\end{tabular}

The packer of the tester $146 \mathrm{~mm}$ in diameter was fixed at a depth of $3343 \mathrm{~m}$ (MD). For limiting the difference of pressures exerted on the perspective horizon during the tests, the displacement fluid of $400 \mathrm{~m}$ of column, $1200 \mathrm{~kg} / \mathrm{m}^{3}$ of density (light mud) and $1.3 \mathrm{~m}^{3}$ of volume was used in the DST string.

The two-cycle tests were performed, i.e. two flow periods and two build-up periods. During the first build-up test lasting on the whole 50 minutes a combustible gas was liberated from the string for 40 minutes. This gas was present above the periodic rotary cut-off valve from where was liberated from the displacement fluid. During the second flow test (on the whole 240 minutes) the gas was outflowing from the adjustable orifice for 120 minutes during which 150 liters of displacement fluid were collected. Then gas was collected on the orifice 18/64" of diameter, during which 20 liters of displacement fluid were collected. The wellhead pressure on the beginning of the outflow equaled to $P_{p}=9$ bar, and at the end $P_{k}=28$ bar. The gas yield equaled to $q_{g}=15 \mathrm{Nm}^{3} / \mathrm{min}$. For the successive 60 minutes gas was received on the orifice 14/64", at pressures $P_{p}=28$ bar and $P_{k}=30$ bar. 
No displacement fluid was carried out with gas and the gas rate equaled to $q_{g}=10 \mathrm{~m}^{3} / \mathrm{min}$. In this way an information about the positive productivity indices for the drilled horizon was obtained.

During the second build-up test lasting for 240 minutes, gas accumulated in the column of displacement fluid was released from the string for 60 minutes. During the second pressure build-up the string was filled with mud, the diaphragm circulation valve was closed with a pressure difference of 100 bar and the wellbore was washed above the DST set on the left side. A gas sample was collected in an autoclave at a pressure of 60 bar and then analyzed in the laboratory.

The gas had the following physical properties:

- compressibility factor $z=0.96551$;

- dynamic viscosity coefficient of gas $\mu_{g}=0.0139975$ [cP];

- gas volume coefficient $B_{g}=0.0147746\left[\mathrm{~m}^{3} / \mathrm{Nm}^{3}\right]$;

- gas compressibility coefficient $\mathrm{c}_{\mathrm{g}}=0.0128004\left[\mathrm{bar}^{-1}\right.$;

- relative density of gas $\rho_{g}^{\prime}=0.7661$;

- pseudocritical temperature of gas mixture $T_{k r}=158.518[\mathrm{~K}]$;

- pseudocritical pressure of gas mixture $P_{k r}=40.5573$ [bar].

The lower part of the weighting set was observed to contain sand when dragging out the DST, which proves that gas production from the Rotliegend may be accompanied by a disadvantageous phenomenon of sanding up, therefore sand filter should be used or gas rate significantly limited.

\subsection{Interpretation of test results}

The results of the test were interpreted with the log-log method using a computer software by a French company Kappa [10, 9]. The log-log method [1, 2, 3] lied in comparing real and model (diagnostic) plots of pressure build-up and first derivative of pressure increments in a function of time in a double-logarithmic system. The diagnostic plots of bottomhole pressure build-up $(\Delta p)$ registered during the build-up test and the first derivative of bottomhole pressure build-up in a function of time $\left(\Delta p^{\prime}\right)$ were analyzed in a double-logarithmic scale.

A theoretical model of deposit can be selected and flow conditions in deposit identified on the basis of the diagnostic plots by comparing these conditions with the real ones. By comparing these plots in a double-logarithmic scale one could analyze their characteristic course in reference to the coordinates axes and evaluate various phenomena in the near wellbore area (e.g. storage effect, skin effect) and reservoir phenomena (homogeneous or heterogeneous deposit, radial composite or linear composite deposit, infinite acting radial flow), presence of deposit boundaries. Diagnostic plot of bottom hole pressure and first derivative of bottom hole pressure for G-1k well is presented on the Figure 2. 


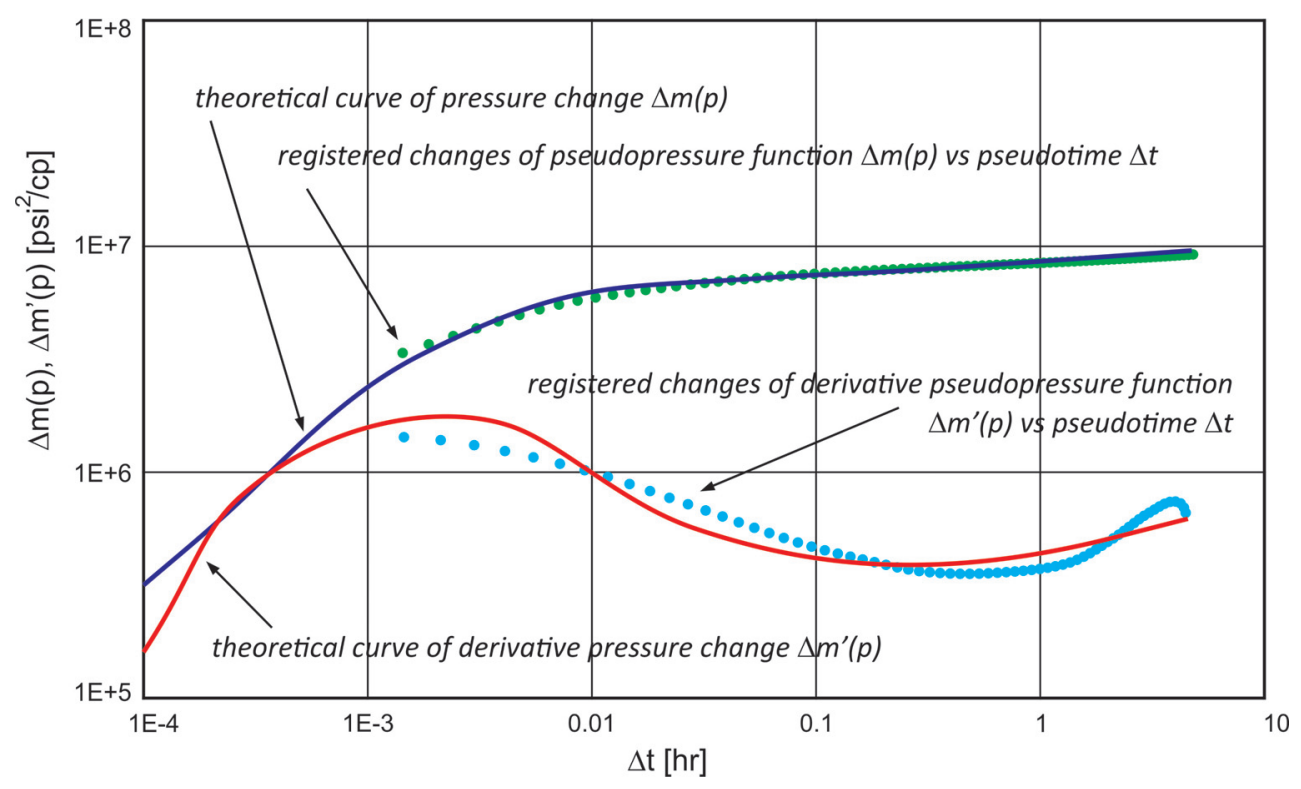

Fig. 2. Diagnostic plot for G-1k well [10]

\section{Evaluation of deposit productivity}

Among very important productivity indices obtained with DST method are the following reservoir parameters:

- gradient of reservoir pressure $0.0256 \mathrm{bar} / \mathrm{m}$ (abnormal low pressure reservoir was opened with a directional well);

- hydroconductivity for gas $k \cdot h=137[\mathrm{mD} \cdot \mathrm{m}]$;

- rock permeability $k=13.7[\mathrm{mD}]$;

- productivity index $J=114.851\left[\mathrm{~m}^{3} / \mathrm{h} / \mathrm{bar}\right]$.

Above productivity indices show that the analyzed Rotlegend was of minimum commercial value. No absolute gas production index $V_{a b s}$ was given.

The results of the analysis of productivity index of the Rotliegend determined on the basis of DST tests along with the estimation of commercial value of the analyzed wellbores are presented in Table 2. Each of the five tests provides a sufficient number of reliable data on the basis of which the productivity of the analyzed part of the natural gas deposit could be analyzed and interpreted.

The first two instances of DST tests (Tab. 2) clearly indicate that gas can be produced. In the first case the deposit is of low commercial value, mainly due to the fact that G-1k well is placed on a partly depleted part of deposit (lower gradient of reservoir pressure of $0.026 \mathrm{bar} / \mathrm{m})$. In the second case the analysis of the productivity confirmed good commercial value of SW-4 well. In the third case (SW-5 well) (Tab. 2) the hydroconductivity and permeability of reservoir rocks were low, and the water/gas index very high 
$\left(\mathrm{WG}=1.34 \mathrm{1} / \mathrm{m}^{3}\right)$, therefore this well was considered as unproductive. In the fourth case (WG-1 well) the commercial productivity was sufficient despite the sanding of the well during the DST [10]. In such a situation the production zone of the well should be properly designed (e.g. filter with sand-gravel packer should be applied). In the fifth well (R-1) the gas productivity indices were high, but the DST tests also confirmed serious limitations, i.e. deposit had four boundaries and a high water/gas index $\mathrm{WG}=60 \div 110 \mathrm{ml} / \mathrm{m}^{3}$ ). For this reason the commercial value of this well was assessed as uncertain and thus requiring relative permeability modification [4] and detailed economic analysis.

Table 2

Results of analyses of productivity index for the Rotliegend based on DST data [10]

\begin{tabular}{|c|c|c|c|c|c|c|c|}
\hline No. & Well & $\begin{array}{c}\text { Gradient } \\
\text { of } \\
\text { pressure } \\
p_{z} \\
{[\mathrm{bar} / \mathrm{m}]}\end{array}$ & $\begin{array}{l}\text { Hydro- } \\
\text { conducti- } \\
\text { vity } k \cdot h \\
{[\mathrm{mD} \cdot \mathrm{m}]}\end{array}$ & $\begin{array}{c}\text { Perme- } \\
\text { ability } k \\
\text { [mD] }\end{array}$ & $\begin{array}{c}\text { Gas } \\
\text { productivity } \\
\text { index } W W_{g} \\
{\left[\mathrm{~m}^{3} / \mathrm{h} / \mathrm{bar}\right]}\end{array}$ & $\begin{array}{c}V_{a b s} \\
{[\text { thousand }} \\
\mathrm{m}^{3} / \text { day] }\end{array}$ & Remarks \\
\hline 1 & G-1k & 0.026 & 137 & 13.7 & 114.85 & - & $\begin{array}{l}\text { Abnormal low } \\
\text { pressure. Well } \\
\text { of minimum } \\
\text { commercial } \\
\text { value }\end{array}$ \\
\hline 2 & SW-4 & 0.1114 & 158 & 8.8 & 397.2 & 825.526 & $\begin{array}{l}\text { Good } \\
\text { commercial } \\
\text { value }\end{array}$ \\
\hline 3 & SW-5 & 0.1107 & 1.08 & 0.06 & - & - & $\begin{array}{l}\text { Water index } \\
1.34 \mathrm{l} / \mathrm{m}^{3} \\
\text { No commercial } \\
\text { value }\end{array}$ \\
\hline 4 & WG-1 & 0.113 & 90 & 5 & 246 & - & $\begin{array}{l}\text { Sanded. } \\
\text { Sufficient } \\
\text { commercial } \\
\text { value }\end{array}$ \\
\hline 5 & R-1 & 0.114 & 510 & 170 & 715.2 & 1297.44 & $\begin{array}{l}\text { Water index } \\
60-110 \mathrm{ml} / \mathrm{m}^{3} \text {. } \\
\text { Deposit limited } \\
\text { by four faults. } \\
\text { Uncertain } \\
\text { commercial } \\
\text { value }\end{array}$ \\
\hline
\end{tabular}

\section{Evaluation of permeability changes in reservoir rocks in the wellbore zone}

The skin-effect coefficient $(S)$ expresses drop of pressure $(\Delta p s)$ generated while fighting the hydraulic resistance in the wellbore area by reservoir fluid flowing to the well. 
When the skin effect is positive, the permeability of rocks in the zone is damaged; for $S=0$ no changes are observed. When the skin effect is negative, the permeability of the rock in that zone improves.

In the analyzed case the industrial skin effect index was $S=+4.17$. It was positive, therefore deteriorated permeability conditions of rocks in the DST tested area could be expected. The radius of the analyzed zone was $61.9 \mathrm{~m}$. No deposit boundaries in the form of faults or wedgings were observed in that zone.

Table 3

Skin-effect indices determined with the log-log method for the Roliegend based on DST results [10]

\begin{tabular}{|l|c|c|c|c|l|}
\hline Well & $\begin{array}{c}\text { Depth of } \\
\text { analyzed } \\
\text { horizon } \\
{[\mathrm{m}]}\end{array}$ & $\begin{array}{c}\text { Mud } \\
\text { repressure } \\
\left(p_{h}-p_{z}\right) \\
{[\mathrm{bar}]}\end{array}$ & $\begin{array}{c}\text { Skin- } \\
\text { effect } \\
\text { index }\end{array}$ & $\begin{array}{c}\text { Radius of } \\
\text { zone analyzed } \\
\text { with DST } \\
R_{b}[\mathrm{~m}]\end{array}$ & \multicolumn{1}{|c|}{ Remarks } \\
\hline G-1k & $3113-3125.8$ & 286.6 & +4.17 & 61.9 & $\begin{array}{l}\text { Damaged permeability of rocks } \\
\text { caused by too high repressure } \\
\text { on reservoir }\end{array}$ \\
\hline SW-4 & $3567.9-3586$ & 36.2 & +0.125 & 87 & $\begin{array}{l}\text { Minimum damage of permeability } \\
\text { of rocks }\end{array}$ \\
\hline SW-5 & $3540-3558$ & 36.64 & +0.09 & 7.4 & Permeability undamaged \\
\hline WG-1 & $3518-3536$ & 25.84 & $>+5$ & No data & $\begin{array}{l}\text { High sanding up of deposit } \\
\text { blocked the wellbore area }\end{array}$ \\
\hline R-1 & $2675-2680$ & 19.75 & +2.18 & $>500$ & $\begin{array}{l}\text { Four boundaries of deposit } \\
\text { found }\end{array}$ \\
\hline
\end{tabular}

The results of an evaluation permeability changes of the Rotliegend in the wellbore zone are listed in Table 3. In all analyzed cases the permeability of reservoir rocks was observed to be only slightly damaged. This could be caused by excessive repressing of the mud column in the well (e.g. G-1k well) or excessive sanding of the deposit (e.g. WG-1 well).

\section{Evaluation of facial changes of the Rotliegend in the DST tested area}

The interpretation of the DST results in G-1k and SW-4 wells revealed (Tab. 3) that the Rotliegend in the analyzed zone has a radial composite build. This means that the analyzed strata have facial changes which influence on the filtration conditions of reservoir fluid. The model assumptions for the radial reservoir layer are the following: well is in the center of a homogeneous and radial zone. The well hydraulically contacts with the homogeneous layer of infinitely distant boundaries. The outer and inner zones have different hydrodynamic characteristics or house different reservoir fluids. No pressure drop on the edge of the layer is observed (Fig. 3). 
The model parameters are as follows:

- $k h$ - hydroconductivity;

- $R_{i}$ - distance between well and boundary of facial change;

- $M$ - mobility coefficient ( $k / \mu$ inner zone) / $(k / \mu$ outer zone);

- $D$ - diffusivity coefficient $\left(k / f \mu c_{t}\right.$ inner zone) $/\left(k / f \mu c_{t}\right.$ outer zone). where: $k$ - permeability of rocks; $f$ - porosity of rock; $\mu$ - coefficient of dynamic viscosity of reservoir fluid; $c_{t}-$ compressibility of reservoir rock.

a)

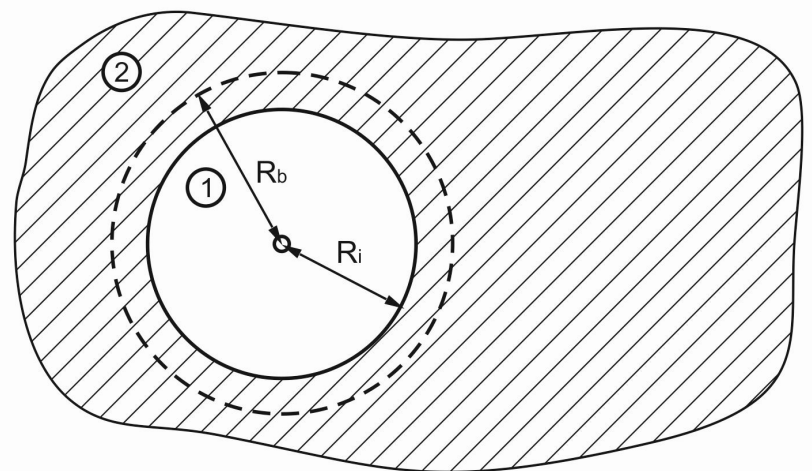

b)

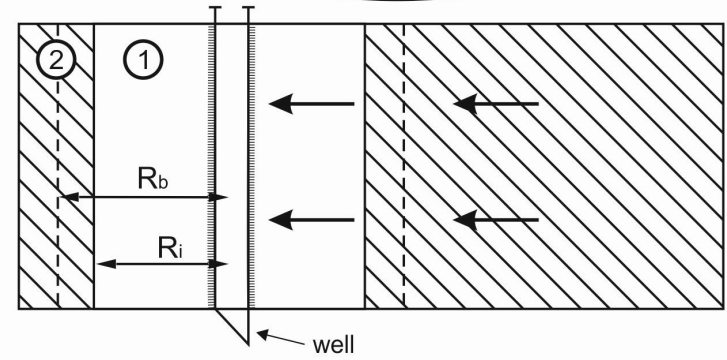

c)

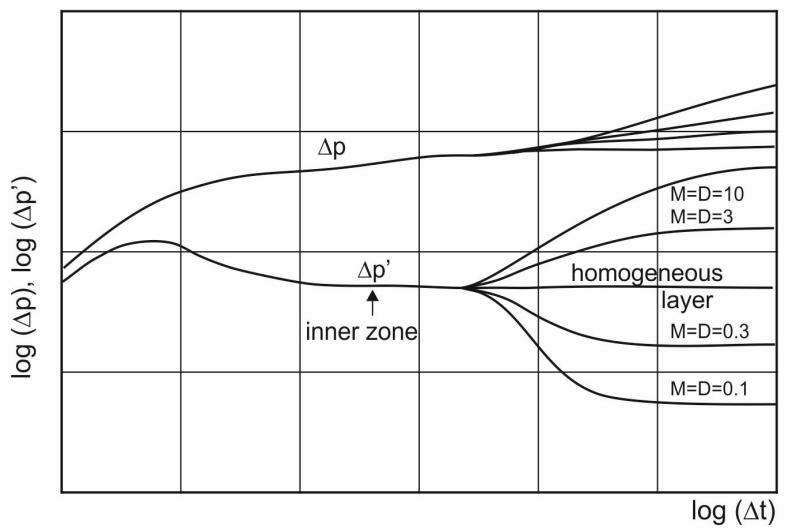

Fig. 3. Radial deposit layer: a) and b) model of layer; c) double-logarithmic model plot [9] 
The shape of plots in a double logarithmic system is presented in Figure 3c. Initially the derivative plot resembles that of a homogeneous layer. This refers to the inner zone. After the transient period is over, the layer exhibits properties of the second homogeneous (outer) zone. The pressure derivative plot may indicate two periods of stabilization. The length of the transient time between these two zones is a product of $R_{i} \cdot E D$ and quotient $k / f \mu c_{t}$ for the inner zone. The ratio of both derivatives gives their mobility. The shape of the plot in the transient period of two homogeneous behaviors is a function of $M$ and $D$. If the fluid storing increases from the inner to the outer zone, the derivative plot in the transient period tends to an indention resembling that of a transient period in the double porosity model. When the storage capacity changes inversely, a convex shape appears on the plot. The shape of the plot is a function of a dimensionless expression $R_{i} E D$.

In the first two analyzed cases an assumption was made that in the radial deposit the G-1k and SW-4 wells are sited in more profitable reservoir zones (M and D are bigger than 1). In the remaining three cases the shape of the pressure plots was influenced by the following factors (Tab. 4): too high and too diversified saturation with water (SW-5 well); very high sanding up (presence of sand in the tester in WG-1 well); presence of deposit boundaries in the analyzed zone (R-1 well).

\section{Table 4}

Model parameters of facial changes of the Rotliegend and remarks on the lack of information about these changes from the DST test [10]

\begin{tabular}{|l|c|c|c|c|c|l|}
\hline Well & $\begin{array}{c}k \cdot h \\
{[\mathrm{mD} \cdot \mathrm{m}]}\end{array}$ & $\begin{array}{c}R_{i} \\
{[\mathrm{~m}]}\end{array}$ & $\begin{array}{c}M \\
{[-]}\end{array}$ & $\begin{array}{c}D \\
{[-]}\end{array}$ & $\begin{array}{c}\text { Radius } \\
\text { of analyzed } \\
\text { zone, } R_{b} \\
{[\mathrm{~m}]}\end{array}$ & \multicolumn{1}{|c|}{ Remarks } \\
\hline G-1k & 137 & 29.8 & 3.54 & 3.54 & 61.9 & Well in a better deposit zone? \\
\hline SW-4 & 158 & 7.26 & 3.1 & 3.1 & 87.2 & Well in a better deposit zone? \\
\hline SW-5 & 1.08 & - & - & - & 7.38 & $\begin{array}{l}\text { High value of water index } \\
1.34 \text { l/m proves high saturation } \\
\text { of rocks with reservoir water, } \\
\text { which disturbs the interaction } \\
\text { of facial zones during } \\
\text { the DST test }\end{array}$ \\
\hline WG-1 & 90 & - & - & - & No data & $\begin{array}{l}\text { High sanding up of the deposit } \\
\text { during DST test may cause } \\
\text { considerable filtration changes } \\
\text { of reservoir rocks }\end{array}$ \\
\hline R-1 & 510 & - & - & - & $>500$ & $\begin{array}{l}\text { Dominance of four boundaries } \\
\text { of deposit blurs possible occurrence } \\
\text { of facial changes }\end{array}$ \\
\hline
\end{tabular}




\section{CONCLUSIONS}

1. The scope of DST results for hydrocarbons prospecting covers, e.g.:

- finding gas- and oil-bearing horizons in the profile of geologic-prospecting wells;

- evaluation of gas- and oil-bearing horizons for their productivity (particularly their commercial value);

- reservoir characteristic (type of reservoir rock, basic reservoir parameters, permeability changes in reservoir rocks in the wellbore zone);

- model of the reservoir, characteristic of the supply system of the analyzed well and type of deposit boundaries.

2. Presented analysis of industrial data on gas-bearingness of the Rotliegend horizon in the Polish Lowland shows to a considerable applicability of DST tests as far as the assessment of reservoir conditions and their variability in the DST zone goes.

3. The facial changes in the Rotliegend can be confirmed by the DST data. On this basis the development and production method can be properly selected. However in the industrial practice the information about the radial or linear build of the deposit is dominated by: the boundaries of deposit (faults, wedgings); excessive sanding; and also excessively diversified saturation of the gas-bearing horizon with reservoir water.

\section{REFERENCES}

[1] Economides C.A., Economides M.J.: Basic Well Test Interpretation. Introduction to Well Testing. March University of Houston 1998.

[2] Dubiel S., Rybicki C., Zubrzycki A., Maruta M.: Interpretation of DST test results for the identification of HC accumulation limits or boundaries in the area of the Carpathians and Carpathian Foredeep (South Poland). AGH Drilling Oil Gas, vol. 31, No. 2, 2014, 291-306.

[3] Dubiel S., Chrząszcz W., Rzyczniak M.: Problemy opróbowania warstw perspektywicznych rurowymi próbnikami zloża. Wydawnictwa AGH, Kraków 2003.

[4] Falkowicz S., Dubiel S., Cicha-Szot R.: Laboratoryjne studium porównawcze środków chemicznych stosowanych $w$ zabiegach ograniczania doplywu wody do odwiertów gazowych. Comparative laboratory tests of products for selective control of water in gas wells. Gospodarka Surowcami Mineralnymi, t. 30, z. 3, Wydawnictwo IGSMiE, Kraków 2014.

[5] Jarzyna J. et al.: Variability of the Rotliegend sandstones in the Polish part of the southern Permian Basin - permeability and porosity relationships. Annales Societatis Geologorum Poloniae, vol. 78, No. 1, 2009, 13-26.

[6] Karnkowski P.H.: Origin and Evolution of the Polish Rotliegend Basin. Polish Geological Institute Special Papers 3, Warszawa 1999. 
[7] Kiersnowski H.: Depositional development of the Upper Rotliegend Basin and evolution of its sediment source areas. Geological Quarterly, vol. 41, No. 4, 1997, 433-456.

[8] Maćkowski T.: Analiza karbońsko-dolnopermskiego systemu naftowego $w$ aspekcie poszukiwań pułapek litologicznych i strukturalnych $w$ utworach czerwonego spqgowca w strefie Śrem - Kalisz - Konin. PhD Thesis, AGH UST, 2008.

[9] Well test interpretation for monophasicoil and gas by analysis of pressure behavior. Proccedins of Schlumberger, Warszawa 19-20.01.1993.

[10] Wydział Wiertnictwa, Nafty i Gazu Kraków, 2014 (unpublished).

[11] Muszyński M.: Środowisko sedymentacji i spoiwo osadów górnego czerwonego spqgowca obszaru niecki poznańskiej. Przegląd Geologiczny, t. 47, nr 5, 1999.

[12] Oprogramowanie interpretacji testów otworowych firmy Kappa. ZPNiG Kraków, 1995. 